\title{
The arthritis of mixed connective tissue disease
}

\author{
ROBERT M. BENNETT AND DENIS J. O'CONNELL \\ From the Department of Medicine, University of Oregon Health Sciences Center, Portland, Oregon, USA and \\ the Department of Radiology, University of Chicago, Chicago, Illinois, USA
}

SUMMARY Twenty patients with mixed connective tissue disease were followed for 5 years. Arthritis occurred in all 20 patients, being the presenting complaint in 11 patients. The joints most frequently involved were the proximal interphalangeal (PIP), metacarpophalangeal (MCP), wrists, metatarsophalangeal (MTP), and knee; the distribution tended to be symmetrical, mimicking early rheumatoid arthritis. Joint deformities occurred in 6 patients, but apart from 1 patient with arthritis mutilans, significant functional impairment was not encountered. Radiologically small punched out bone erosions, asymmetrically distributed, were the most characteristic finding; other notable changes were aseptic necrosis, tuft erosions, and periarticular calcification. Joint effusions were noninflammatory, the cellular content was predominantly lymphocytic and the C3 level was normal. Most cases were controlled with non-steroidal anti-inflammatory agents and invariably responded to prednisone $\leqslant 7 \cdot 5 \mathrm{mg} /$ day.

In 1972 Sharp and his co-workers (Sharp et al., 1972) described an overlap syndrome of systemic lupus erythematosus (SLE), progressive systemic sclerosis (PSS), and polymyositis which they considered a distinct rheumatic disease syndrome giving it the name 'mixed connective tissue disease' (MCTD). The unifying feature of this group of patients was the presence of antibodies to a saline soluble nuclear antigen (ENA), which was RNAse sensitive. Subsequent work has resolved ENA into two distinct moieties which are probably covalently linked: soluble ribonucleoprotein (RNP) and a glycoprotein termed Sm antigen (Mattioli and Reichlin, 1977). RNAse sensitive ENA is synonymous with RNP. Antibodies to RNP are a sine qua non for the diagnosis of MCTD, albeit not specific, being found in a small proportion of patients with classical scleroderma and SLE (Reichlin and Mattioli, 1972; Parker, 1973; Sharp et al., 1976). More recent studies have indicated that anti-Sm antibodies are restricted to patients with SLE (Notman et al., 1975). The concept of MCTD as a distinct clinical entity has not been generally accepted. It has been suggested that the MCTD syndrome is most compatible with SLE favourably modified by

Accepted for publication January 11, 1978

Correspondence to Dr Robert M. Bennett, Division of Immunology, Allergy and Rheumatology, University of Oregon Health Sciences Center, 3181 S. W. Sam Jackson Park Road, Portland, Oregon 97201, USA the presence of RNP antibodies (Reichlin and Mattioli, 1974; Reichlin, 1976). In the initial report of MCTD serious complications, as found in SLE, were conspicuously lacking. However, subsequent experience has led to the recognition of both renal disease (Bennett and Spargo, 1977a; Fuller et al., 1977) and neuropsychiatric problems (Bennett and Spargo, 1977b). Arthralgias and arthritis have been the commonest clinical finding (Sharp et al., 1972; Reichlin, 1976). Indeed the most frequent initial diagnosis in our series of patients was early rheumatoid arthritis (RA) or juvenile rheumatoid arthritis (JRA). This present study reports on the articular manifestations in 20 patients with MCTD each followed for 5 years.

\section{Patients and methods}

The criteria applied for the diagnosis of MCTD were: (1) a speckled pattern of antinuclear immunofluorescence $\geqslant 1: 480$; (2) RNAse sensitive ENA haemagglutination titre $\geqslant 1: 6400$; (3) persistently absent antibodies to double stranded DNA (dsDNA) and Sm antigens; (4) sequential or concurrent clinical 'overlap' of features seen in SLE, PSS, RA, and polymyositis.

ENA was prepared according to the procedure described by Sharp et al., (1972). with the exception that calf thymus nuclei were isolated in $2.2 \mathrm{~mol} / 1$ sucrose, $1 \mathrm{mmol} / 1 \mathrm{MgCl}_{2}$, as outlined by Chauveau et al. (1956). 
Tanning and sensitisation of human group $\mathrm{O}$ red blood cells were performed as previously described (Eddie-Quartey and Bennett, 1973) with the exception that protein coating was performed at $4^{\circ} \mathrm{C}$ rather than $37^{\circ} \mathrm{C}$. Ribonuclease digestion of ENA-coated cells was achieved by incubating a $33 \%$ suspension in phosphate buffered saline, $p \mathrm{H} 6.8$ in the presence of $0.2 \mathrm{mg}$ RNAse (Sigma Chemicals) for 1 hour at $35^{\circ} \mathrm{C}$.

Doubling dilutions of the patient's serum in PBS, started at a titre of 1:100. After the addition of $0.025 \mathrm{ml}$ of a $1 \%$ suspension of ENA-coated erythrocytes the haemagglutination titre was read after $45 \mathrm{~min}$ incubation at $37^{\circ} \mathrm{C}$. Controls. with RNAse treated cells and uncoated cells were run concomitantly. The presence of anti-RNP antibodies and absence of anti-Sm antibodies was further verified by the method of counterimmunoelectrophoresis (Kurata and Tan, 1976).

Antibodies to dsDNA were assayed by a modified Farr technique as previously described (Bennett and Molina, 1976). The purity of the dsDNA, in terms of small single stranded regions, was monitored by benzoylated, naphthoylated DEAE cellulose chromotography and S1 endonuclease digestion as we have previously outlined (Locker et al., 1977). The dsDNA used to assay the patient's sera was less than $3 \%$ contaminated with single stranded regions; sera from normals and rheumatoid diseases other than SLE, bound less than $0.5 \mu \mathrm{g}$ of $\mathrm{dsDNA} / \mathrm{ml}$ serum.

Skeletal $x$-rays were obtained with fine detail film as previously described by Genant et al. (1976).

\section{Results}

The initial onset of symptoms attributable to MCTD occurred over an age range from 14 years to 56 years; mean age 35 . Six patients had an onset in their twenties. Three had a juvenile onset and in the remainder the disease started after the age of 30 . There was a marked female to male preponderance, 18:2. Fourteen patients were Caucasians and 6 were of African descent.

\section{INITIAL SYMPTOMS}

Although joint pains or frank arthritis were present in all 20 patients at some time during the course of the disease, Raynaud's phenomenon was the commonest initial symptom. Other presenting symptoms are listed in Table 1. Arthritis was the initial symptom in 11 patients and in 5 patients there was a concomittant Raynaud's phenomenon. Early rheumatoid arthritis was the initial diagnosis in 9 patients, other diagnoses and the most compatible 'follow-up' diagnosis (excluding MCTD) are given in Table 2.

\section{CLASSIFICATION BY ARA CRITERIA}

Employing the criteria of the American Rheumatisn $\overrightarrow{\mathrm{F}^{3}}$ Association for the diagnosis of rheumatoid arthritis (Ropes et al., (1959), omitting 'exclusion diagnoses $\frac{\tau}{0}$ 12 patients could be classified as having classicat RA. On the other hand, utilising the preliminar criteria for the diagnosis of SLE, $16(80 \%)$ patients could equally well be labelled with this diagnosis (Cohen et al., 1971). If a high titre of antinuclea $\vec{D}$ immunofluorescence is substituted for a positive $\mathrm{LE}$ cell preparation as previously suggested (Trimble $e \xi$ al., 1974), all 20 patients satisfy the criteria for SLE These findings are summarised in Table 3.

\section{CLINICAL FEATURES OF THE ARTHRITIS}

Involvement of the MCPs and PIPs occurred in afi patients, usually commencing as an intermittent arthralgia and progressing to clinically eviden synovitis. In 2 patients progression of arthralgia to arthritis did not occur. The frequency of joind involvement is shown in Table 4. Generally the artho ritis was mild, but persistent deformities were observe $\$$ in 7 patients; ulnar deviation in 3 cases; subluxe MCPs in 2 patients; claw toes in 2 patients; swabo

Table 1 Initial symptoms in MCTD

\begin{tabular}{|c|c|c|}
\hline Symptom & Presenting problem & Later presentation \\
\hline Raynaud's phenomenon & $13(65 \%)$ & $2(10 \%)$ \\
\hline Joint pain & $11(55 \%)$ & $9(45 \%)$ \\
\hline Hand swelling & $4(20 \%)$ & $2(10 \%)$ \\
\hline Fever & $2(10 \%)$ & $7(35 \%)$ \\
\hline Erythema nodosum & $1(5 \%)$ & $1(5 \%)$ \\
\hline Trigeminal neuropathy & $1(5 \%)$ & $1(5 \%)$ \\
\hline
\end{tabular}

Table 2 Initial and later diagnoses in MCTD population

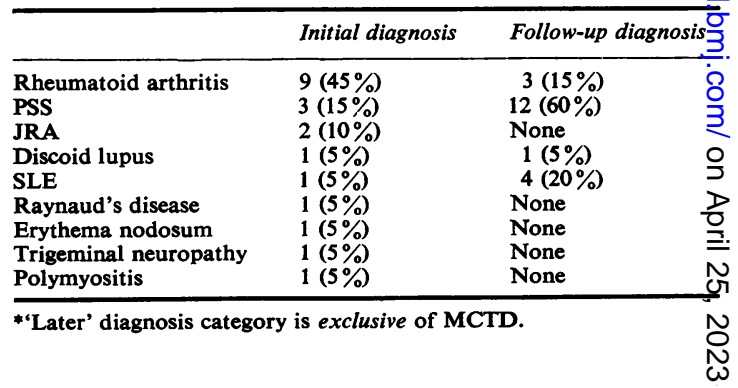

Table 3 Application of 'diagnostic criteria' to MCTD 우 population

\begin{tabular}{|c|c|}
\hline $\begin{array}{l}\text { Rheumatoid arthritis } \\
\text { Classical } \\
\text { Probable } \\
\text { Possible }\end{array}$ & $\begin{array}{r}12(60 \%) \\
5(25 \%) \\
3(15 \%)\end{array}$ \\
\hline $\begin{array}{l}\text { Systemic lupus erythematosus } \\
\text { Preliminary criteria } \\
\text { Revised criteria* }\end{array}$ & $\begin{array}{l}16(80 \%) \\
20(100 \%)\end{array}$ \\
\hline
\end{tabular}

* Revised criteria substitute a high titre ANIF for a positive LE cadr preparation. 
neck deformities in 1 patient; arthritis mutilans in 1 patient; flexion contractures of the fingers in 1 patient (see Figs. 1, 2, and 3). Except for the 1 patient with arthritis mutilans, no significant loss of joint function was encountered. Effusions were infrequent

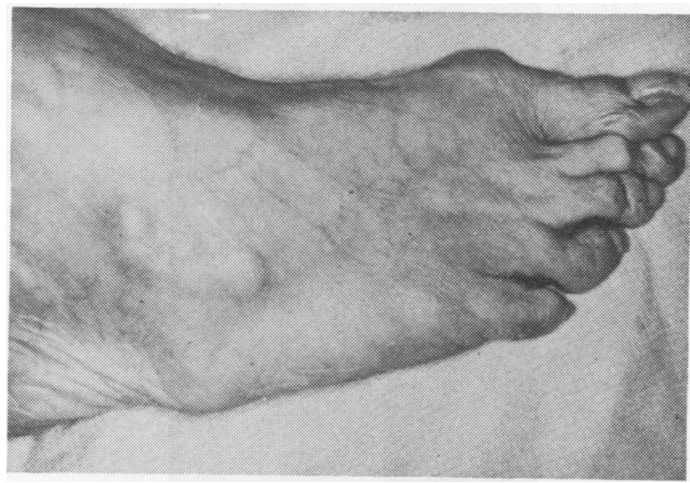

Fig. 1 Foot of a patient with MCTD of 30 years' duration.

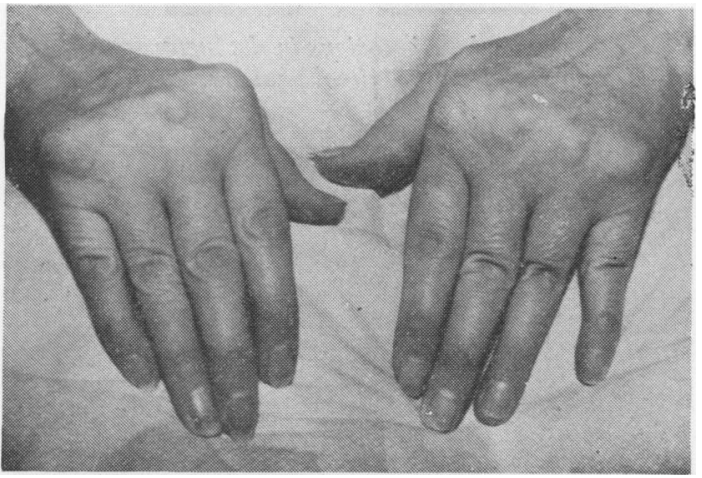

Fig. 2 Longstanding MCTD in a 45 year old woman showing early ulnar deviation, swan neck deformities, and subluxed MCP joints.

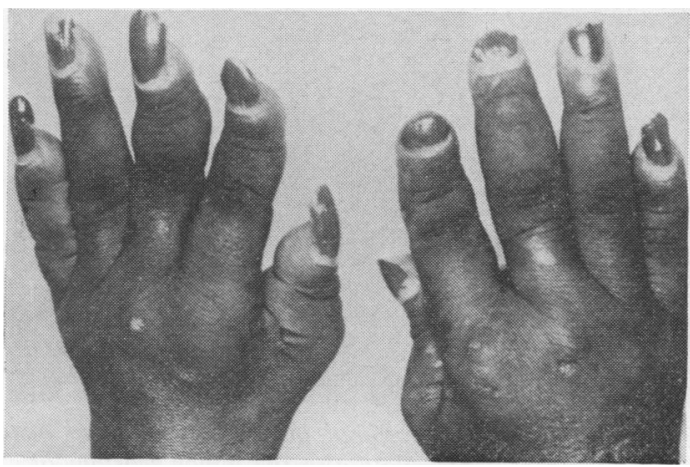

Fig. 3 MCTD in a patient with biopsy proven discoid LE, showing arthritis mutilans.
Table 4 Distribution of joint involvement in MCTD

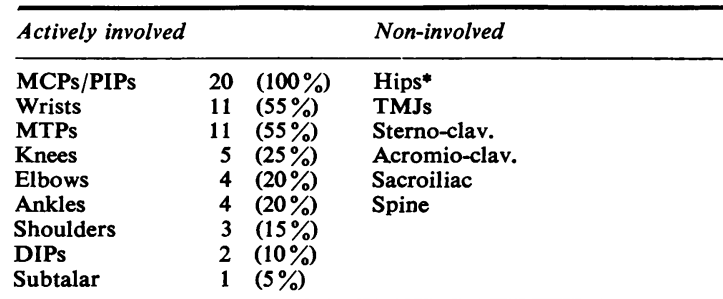

*One patient had aseptic necrosis of femoral head, possibly iatrogenic in origin.

and transient and were only detected in the knees. Palpable synovial proliferation did not have the 'exuberant' quality seen in RA. Tendon sheath synovial proliferation was not encountered. Symptomatic aseptic necrosis occurred in 3 patients: bilateral hips, one knee, and both pedal naviculars. Two of these patients had been on prednisone 12.5 $\mathrm{mg} /$ day and $10 \mathrm{mg} /$ day at the onset of the aseptic necrosis. In another 2 instances asymptomatic aseptic necrosis was seen at radiography, involving both carpal naviculars in 1 patient and a medullary bone infarct shaft of the right humerus in another.

In the majority of patients joint symptoms could be adequately controlled with non-steroidal antiinflammatory agents. Three patients required low dose steroids, prednisone $5 \mathrm{mg}$ to $7.5 \mathrm{mg}$, to achieve a satisfactory control of joint inflammation.

\section{HISTOLOGY}

Proliferative synovitis was not a conspicuous feature of the arthritis in most patients. The patient with arthritis mutilans underwent fusion of the right wrist and a specimen of bone and synovium was obtained at operation (Fig. 4). There was synovial cell proliferation with a chronic inflammatory cell infiltrate without any follicle formation. Cartilage had been completely destroyed.

\section{LABORATORY FINDINGS}

As previously defined, all patients studied had RNP antibodies in a titre of $\geqslant 1: 6400$, a speckled pattern of antinuclear immunofluorescent $\geqslant 1: 480$, and persistently absent antibodies to dsDNA and the Sm antigen The titre of RNP antibodies did not correlate either positively or negatively with the extent of active joint inflammation or other manifestations of disease activity.

Rheumatoid factor was present in 5 patients. The highest values (SCAT 1:5120 and 1:1280) were seen in 2 patients with a disease most consistent with PSS; one of these patients had ulnar deviation and minor erosive changes radiologically. In the 3 patients whose 'follow-up' diagnosis was most 


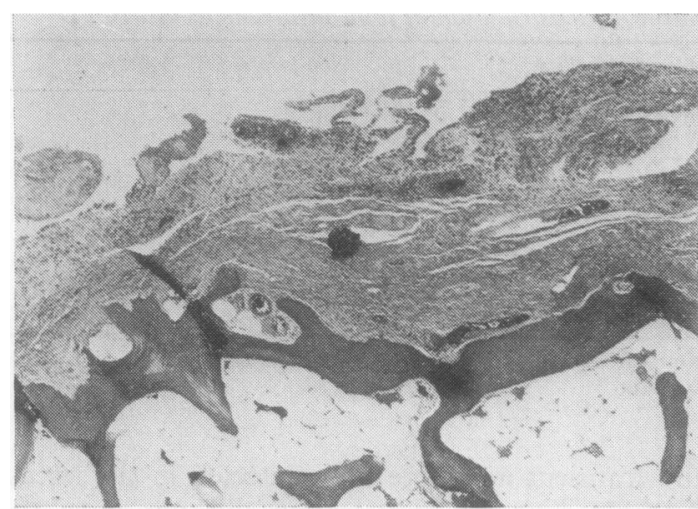

Fig. 4 Specimen of bone and synovium obtained during an ulnar resection of the patient with arthritis mutilans. There is a complete loss of cartilage with synovial erosion of bone; the synovial membrane is greatly hypertrophied with increased vascularity and is infiltrated with mononuclear cells.

compatible with rheumatoid arthritis, rheumatoid factor was persistently absent from their sera.

An elevated erythrocyte sedimentation rate was encountered in all patients at some time in the course of their disease; it tended to be related to systemic manifestations of MCTD rather than the joint involvement.

An anaemia of chronic inflammation was found in $75 \%$ of patients and this usually correlated with a hypergammaglobulinaemia. A reduced serum $\mathbf{C}^{\mathbf{4}}$ level was seen in $30 \%$ of patients, the reduction tended to be a transient and sometimes fluctuating phenomena not obviously related to disease activity.

Only 2 specimens of synovial fluid were obtained; in both cases there was a good viscosity and normal mucin clot, white cells were $2500 / \mathrm{mm}^{3}\left(2.5 \times 10^{9} / 1\right.$ lymphocytes $90 \%)$ and $7500 / \mathrm{mm}^{3}\left(7.5 \times 10^{9} / 1\right.$ lymphocytes $70 \%$, respectively. $\mathrm{C}^{3}$ levels were normal relative to synovial fluid protein concentration.

\section{RADIOLOGICAL FEATURES}

Fine detail films of the hands and feet were obtained of all 20 patients. Twelve cases had periarticular erosions in the small bones of the hands and feet. The erosions tended to be few in number and were small and asymmetrically distributed (Figs. 5 and 6).

Table 5 Skeletal radiological features of MCTD

\begin{tabular}{lrl}
\hline Soft tissue swelling & 14 & $(70 \%)$ \\
Marginal erosions & 12 & $(60 \%)$ \\
Tuft erosions & 5 & $(25 \%)$ \\
Aseptic necrosis & 4 & $(20 \%)$ \\
Periarticular osteolysis & 2 & $(10 \%)$ \\
Periarticular osteopenia & 2 & $(10 \%)$ \\
Joint space narrowing & $2(10 \%)$ \\
Periarticular calcification & $1 \quad(5 \%)$ \\
Bony ankylosis & $1 \quad(5 \%)$ \\
\hline
\end{tabular}

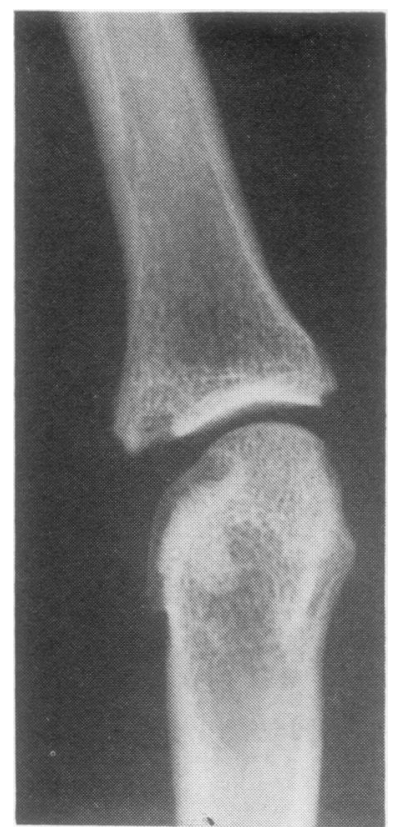

Fig. 5 Small pocketed erosions in the metacarpal head and at the base of the proximal phalanx.

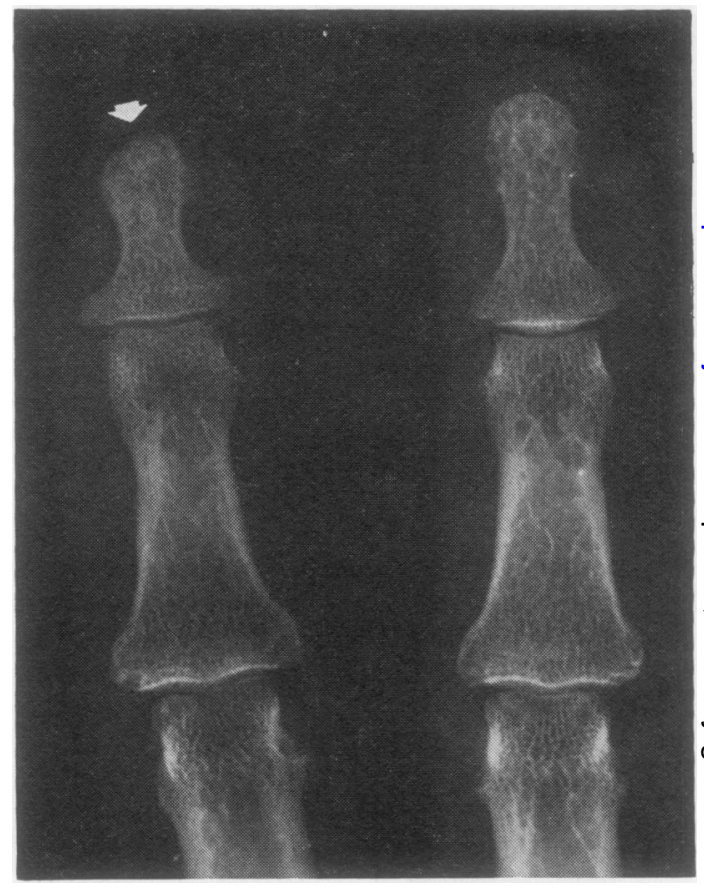

Fig. 6 Erosions at proximal interphalangeal and dista interphalangeal joints. Note also the minor erosions of the tuft of the distal phalanx (arrow) with adjacent soft tissue atrophy. 
In 2 of these 12 cases, the only abnormality was an isolated erosion in the base of the phalanx or in the styloid process of the ulna. Associated soft tissue swelling was seen in all 12 of the patients with bone erosions. Two cases had a severe destructive arthritis with extensive resorption of bone in the carpus and fingers. The pattern of bone destruction resembled psoriatic arthritis. (Fig. 7)

Joint space narrowing was unusual and was seen in only 2 patients, both of whom had a mild erosive arthritis. The bone density in the hands and feet tended to be well preserved, even in the patients with bone erosions. Generalised osteopoenia was appreciated in 4 patients, 2 of whom had a severe erosive arthritis. The other 2 had multiple subluxations of the metacarpophalangeal joints with ulnar deviations (Fig. 8). $X$-rays of these latter 2 cases resembled the pattern associated with SLE. In 3 patients, all of whom had metacarpophalangeal and interphalangeal erosions, there were additional erosions in the tufts of the distal phalanges with associated pulp atrophy.

Periarticular calcification around the carpus and several interphalangeal joints was the only abnormality in 1 case.

Avascular necrosis of bone occurred in 5 patients. There was a symmetrical involvement of the hips

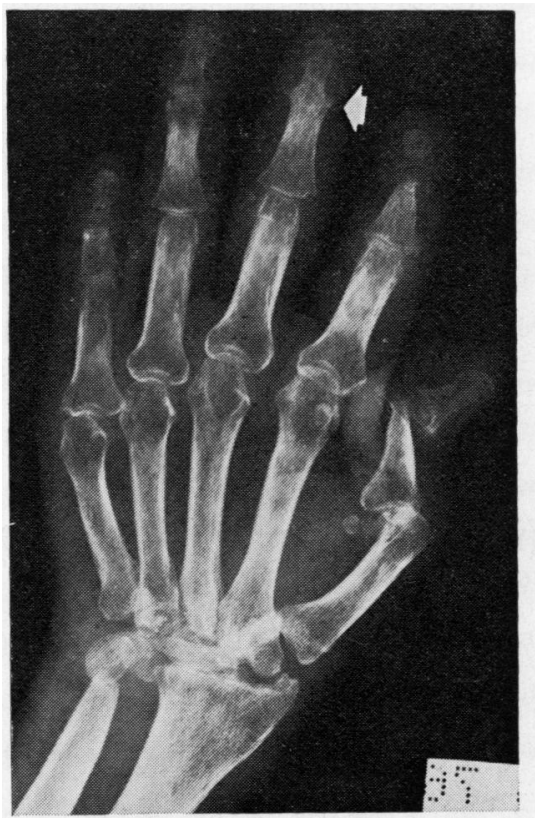

Fig. 7 Destruction of the distal ulna and carpus. There are extensive erosions in the proximal and distal interphalangeal joints, bony ankylosis (arrow), and a 'pencilin-cup' deformity of the distal interphalangeal joint of the thumb. and of the pedal and carpal navicular bones in 4 separate patients. Another patient exhibited avascular necrosis of the lateral femoral condyle of the left knee, and a single patient exhibited a medullary bone infarct in the upper shaft of the right femur. These features are summarised in table 5 .

\section{Discussion}

Within the rheumatic diseases the diagnosis of well established rheumatoid arthritis, progressive systemic sclerosis, dermatomyositis, and systemic lupus erythematosus is usually clearcut. However, the initial manifestations of general malaise, arthralgias, and vascular instability are deceptively similar; a definitive diagnosis usually depending upon a period of careful follow-up to detect a characteristic evolution of physical findings, laboratory tests, and radiological changes. It is the experience of most rheumatologists that at the outset there may be several features characteristic of more than one rheumatic disease, or sometimes during the course of the disease, there may be a progression of one rheumatic disease syndrome into another. Such 'overlap' syndromes have been described for scleroderma and dermatomyositis (Tuffanelli and Winkelmann et al., 1961; Clark et al., 1971), rheumatoid arthritis and scleroderma (Tuffanelli and Winkelmann et al., 1961; Poirer and Rankin, 1972), SLE and polymyositis (Keil, 1940; Estes and Christian, 1971; Dubois, 1973), rheumatoid arthritis and SLE (Haserick, 1955; Sigler et al., 1958; Toone et al., 1960; Dubois 1962; Dubois, 1974), and scleroderma

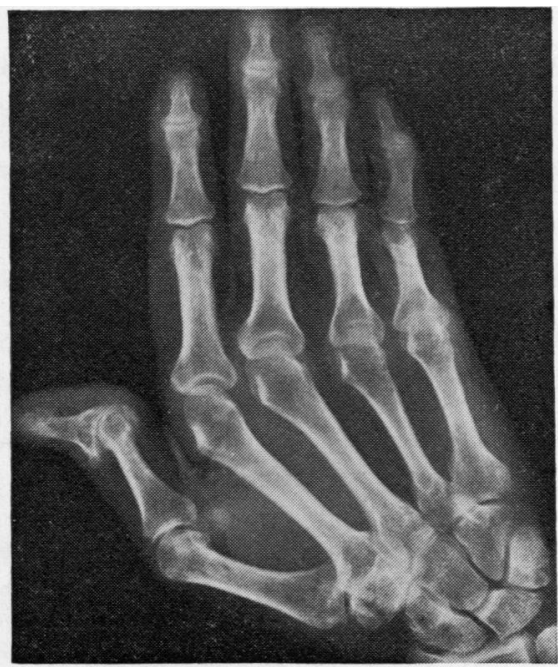

Fig. 8 Mild periarticular osteopoenia and subluxations at the metacarpophalangeal joints and distal interphalangeal joint of the thumb. 
and SLE (Muehrcke et al., 1957; Tuffanelli and Winkelmann, 1961; Rowell, 1962; D'Angelo et al., 1969; Dubois, et al., 1971; Poirer and Rankin, 1972; Dubois, 1974). Whether such associations represent the co-existence of separate diseases, distinct clinical entities, or the more widespread expression of a single rheumatic disease syndrome, has been a source of some controversy.

Lacking well defined aetiological factors, one rationale for the present classification of rheumatic diseases is to aid in planning effective treatment and to provide some estimate of prognosis. In this respect it would seem justifiable to consider MCTD a distinct rheumatic disease syndrome. The prognosis of MCTD is usually good, although renal disease (Bennett and Spargo, 1977a; Fuller et al., 1977) and central nervous system involvement (Bennett and Spargo, 1977b) must now be included in the clinical spectrum. However, such major organ involvement, is generally mild in comparison to classical SLE, and is responsive to relatively small amounts of corticosteroids.

This present study indicates that the arthritis of MCTD is also relatively benign in the majority of cases.

Arthritis was the commonest clinical presentation of MCTD, in over half our patients the initial diagnosis was rheumatoid arthritis or juvenile rheumatoid arthritis. This is similar to the experience of other workers (Sharp et al., 1972; Parker, 1973; Reichlin, 1976; Leibfarth and Persellin, 1976; Sharp et al., 1976) including the onset in childhood (Singsen et al., 1977). The pattern of joint involvement was compatible with a diagnosis of rheumatoid arthritis, but the long term follow-up was unusual in several respects. Even after many years of disease activity joint deformities occurred in only 7 patients. and except for 1 patient with arthritis mutilans, none of the other patients suffered impaired locomotor function. In patients with disease most closely resembling rheumatoid arthritis the rheumatoid factor was persistently negative on long-term follow-up. Except for the case of arthritis mutilans, severe erosive disease was not seen radiologically. However, 12 patients did exhibit minor erosive changes in the hands and feet; these were characterised by an asymmetrical distribution and an appearance best described as small, punched out bone erosions (see Figs. 5 and 6). We believe these radiological findings should suggest a possible diagnosis of MCTD (O'Connell and Bennett, 1977). The patient with arthritis mutilans had co-existent discoid LE and radiologically had 'pencil-in-cup' deformities resembling psoriatic arthritis (see Fig. 7), another patient had similar radiological changes in the toes. These psoriatic-like radiological appearances have been described previously in 1 patient with sclero derma (Wild and Beetham, 1975). We are not aware of a severe destructive arthritis being reported in association with discoid LE. An erosive arthritis of minor degree has been sporadically reported if association with polymyositis (Bunch et al., 1976) SLE (Noonan et al., 1963), and PSS (Rabinowite et al., 1974). Whether the patients described in thes latter reports had what we would now call MCTB is not apparent from the clinical and laboratory data given. It is evident that minor erosive disease will occur, as a reaction to prolonged contiguous synovial inflammation, without respect for oup attempts at an orderly classification of disease. $\quad v_{v}$

Analysis of our patients with MCTD favours ther concept that it represents a relatively undifferent tiated rheumatic disease with a propensity for $\mathrm{d}$ sequential and sometimes concurrent development of features consistent with SLE, PSS, polymyositis and rheumatoid arthritis (R. M. Bennett, R. H Riddell, D. J. O'Connell, and B. H. Spargo, ung published data). We suggest that a high titre of RNP antibodies and absent antibodies to dsDNA and Su antigen, characterise a group of patients with a plures potentiality in their expression of rheumatic disease

Joint pain is the commonest initial complaint is the undifferentiated phase of MCTD and is seem to mimic the early non-specific articular involvemeni of other rheumatic diseases. An increasing aware्? ness of this clinical presentation, coupled wi\$ appropriate serological tests, would help to establis the true prevalence of MCTD and resolve the controversy regarding its nosology.

This work was supported by grants from the Oregon and Ilbitnois Chapters of the Arthritis Foundation and by a Clinical Centre grant from the National Arthritis Foundation.

Since this article was accepted for publication J. T. Halla a J. G. Hardin have described the arthritis of a further $\$ 8$ patients with MCTD (Arthritis and Rheumatism, 1978, 2 497-503).

\section{References}

Bennett, R. M., and Molina, E. (1976). The measurement DNA antibodies. American Journal of Clinical Pathology, 65, 365-367.

Bennett, R. M., and Spargo, B. H. (1977a). Immune comple nephropathy in mixed connective tissue disease. American Journal of Medicine, 63, 534-541.

Bennett, R. M., and Spargo, B. H. (1977b). Neuropsychiatर्tic problems in mixed connective tissue disease. Proceedings of the XIV International Congress of Rheumatolog Abstract 67.

Bunch, T. W., O'Duffy, D. J., and McLeod, R. A. (197\%). Deforming arthritis of the hands in polymyositis. Arthridis and Rheumatism, 19, 243-247.

Chauveau, J., Moule, Y., and Rouiller, C. (1956). Isolatiß̈n of pure and unaltered liver nuclei morphology and ble chemical composition. Journal of Experimental cedl Research, 11, 317-321, 
Clark, J. A., Winkelmann, R. K., and Ward, L. E. (1971). Serological alterations in scleroderma and schlerodermatomyositis. Mayo Clinic Proceedings, 46, 104-107.

Cohen, A. S., Reynolds, W. E., Franklin, E. C., Kulka, J. P., Shulman, L. E., and Wallace, S. L. (1971). Preliminary criteria for the classification of systemic lupus erythematosus. Bulletin of Rheumatic Diseases, 21, 643-648.

D'Angelo, W. A., Fries, J. F., Masi, A. T., and Shulman, L. E. (1969). Pathologic observations in systemic sclerosis. American Journal of Medicine, 46, 428-440.

Dubois, E. L. (1974). In Lupus Erythematosus. Los Angeles, University of Southern California Press.

Dubois, E. L. (1962). Lupus erythematosus, lupoid syndromes and their relation to collagen diseases. Postgraduate Medicine, 32, 468-577.

Dubois, E. L., Chandor, S., Friou, G. J., and Bischel, M. (1971). Progressive systemic sclerosis and localized scleroderma with positive LE cell test and unusual systemic manifestations compatible with systemic lupus erythematosus, Medicine, 50, 199-222.

Eddie-Quartey, A. C., and Bennett, R. M. (1973). A hemagglutination inhibition immunoassay for lactoferrin. American Journal of Clinical Pathology, 60, 574-577.

Estes, D., and Christian, C. L. (1971). The natural history of systemic lupus erythematosus by prospective analysis. Medicine, 50, 85-95.

Fuller, T. J., Richman, A. V., Auerbach, D., Alexander, R. W., Lottenberg, R., and Longley, S. (1977). Immune complex glomerulonephritis in a patient with mixed connective tissue disease. American Journal of Medicine, 62, 761-764.

Genant, H. K., Doi, K., and Mall, J. C. (1976). Comparison of nonscreen techniques (medical vs. industrial film) for fine detail skeletal radiology. Investigative Radiology, 11, 486-500.

Haserick, J. R. (1955). Modern concepts of systemic lupus erythematosus: a review of 126 cases. Journal of Chronic Diseases, 1, 317-334.

Keil, H. (1940). Dermatomyositis and systemic lupus erythematosus. A clinical report of transitional cases with consideration of lead as a possible etiologic factor. Archives of Internal Medicine, 60, 109-139.

Kurata, N., and Tan, E. M. (1976). Identification of antibodies to nuclear acidic antigens by counterimmunoelectrophoresis. Arthritis and Rheumatism, 19, 574-580.

Leibfarth, J. H., and Persellin, R. H. (1976). Characteristics of patients with serum antibodies to extractable nuclear antigens. Arthritis and Rheumatism, 19, 851-856.

Locker, J. D., Medof, M. E., Bennett, R. M., and Sukhupryaraksa, S., (1977). Characterization of DNA used to assay sera for anti-DNA antibodies; determination of the specificities of the anti-DNA antibodies in SLE and non-SLE rheumatic disease states. Journal of Immunology, 118, 694-701.

Mattioli, M., and Reichlin, M. (1977). Physical association of two nuclear antigens and the mutual occurrence of their antibodies; the relationship of the Sm and RNA protein (Mo) systems in SLE sera. Journal of Immunology, 110, 1318-1324.

Muehrcke, R. C., Kark, R. M., Pirani, C. L., and Pollack, V. E. (1957). Lupus nephritis: a clinical and pathological study based on renal biopsies. Medicine, 36, 1-145.

Noonan, C. D., Odone, D. T., Engelman, E. P., and Splitter, S. D. (1963). Roentgenographic manifestations of joint disease in systemic lupus erythematosus. Radiology, 80, 837-843.

Notman, D. D., Kurata, N., and Tan, E. M. (1975). Profile of antinuclear antibodies in systemic rheumatic disease. Annals of Internal Medicine, 83, 464-469.
O'Connell, D. J., and Bennett, R. M. (1977). Mixed connective tissue disease - clinical and radiological aspects of 20 cases. British Journal of Radiology, 50, 620-625.

Parker, M. D. (1973). Ribonucleoprotein antibodies: frequency and clinical significance in systemic lupus erythematosus, scleroderma and mixed connective tissue disease. Journal of Laboratory and Clinical Medicine, 82, 769-775.

Poirer, T. J., and Rankin, G. B. (1972). Gastrointestinal manifestations of progressive systemic scleroderma based on a review of 364 cases. American Journal of Gastroenterology, 58, 30-44.

Rabinowitz, J. G., Twersky, J., and Guttadouria, M. (1974). Similar bone manifestations of scleroderma and rheumatoid arthritis. Radiology, 121, 35-44.

Reichlin, M. (1976). Mixed Connective tissue disease, In Modern Topics in Rheumatology, ed. G. R. V. Hughes, pp. 162-166. Heinemann: London.

Reichlin, M., and Mattioli, M. (1972). Correlation of a precipitin reaction to RNA protein antigen and a low prevalence of nephritis in patients with systemic lupus erythematosus. New England Journal of Medicine, 286, 908-911.

Reichlin, M., and Mattioli, M. (1974). Antigens and antibodies characteristic of systemic lupus erythematosus. Bulletin of Rheumatic Diseases, 24, 756-760.

Ropes, M. W., Bennett, G. A., Cobb, S., Jacox, R., and Jessar, R. A. (1959). Diagnostic criteria for rheumatoid arthritis. 1958 Revision. Annals of the Rheumatic Diseases, 18, 49-53.

Rowell, N. R. (1962). Lupus erythematosus cells in systemic sclerosis. Annals of the Rheumatic Diseases, 21, 70-75.

Sharp, G. C., Irvin, W. S., May, C. M., Holman, H. R., McDuffie, F. C., Hess, E. V., and Schmid, F. R. (1976). Association of antibodies to ribonucleoprotein and Sm antigens with mixed connective tissue disease, systemic lupus erythematosus and other rheumatic diseases. New England Journal of Medicine, 295, 1149-1154.

Sharp, G. C., Irvin, W. S., Tan, E. J., Gould, R. G., and Holman, H. R. (1973). Mixed connective tissue disease an apparently distinct rheumatic disease syndrome associated with a specific antibody to an extractable nuclear antigen (ENA). American Journal of Medicine, 52, 145159.

Sigler, J. W., Monto, R. W., Ensign, D. C., Wilson, G. M., Rebuck, J. W., and Lovett, J. D. (1958). The incidence of the LE cell phenomenon in patients with rheumatoid arthritis (a two-year study). Arthritis and Rheumatism, 1, 115-121.

Singsen, B. H., Bernstein, B. H., Kornreich, H. K., King, K. K., Hanson, V., and Tan, E. M. (1977). Mixed connective tissue disease in childhood. Journal of Pediatrics, 90, 893-900.

Toone, E. C., Irby, R., and Pierce, E. L. (1960). The LE cell in rheumatoid arthritis. American Journal of Medical Science, 240, 599-608.

Trimble, B. R., Townes, A. S., Robinson, H., Kaplan, S. B., Chandler, R. W., Hanissian, A. S., and Masi, A. T. (1974) Preliminary criteria for the classification of systemic lupus erythematosus (SLE). Arthritis and Rheumatism, 17, 184-188.

Tuffanelli, D. L., and Winkelmann, R. K. (1961). Systemic scleroderma; a clinical study of 727 cases. Archives of Dermatology, 84, 359-371.

Wild, W., and Beetham, W. P. (1975). Erosive arthropathy in systemic scleroderma. Journal of the American Medical Association, 232, 511-512. 